\title{
Efeito do extrato alcoólico de própolis sobre a Pasteurella multocida "in vitro" e em coelhos
}

\author{
Regina Conceição Garcia ${ }^{1 *}$, Marcos Eielson Pinheiro de Sá2 ${ }^{2}$ Hélio Langoni² e Sílvia \\ Regina Cunha Funari ${ }^{1}$
}

${ }^{1}$ Centro de Ciências Agrárias, campus de Marechal Cândido Rondon, Universidade do Oeste do Paraná, 85960-000, Marechal Cândido Rondon, Paraná, Brasil. ${ }^{2}$ Médico Veterinário. *Autor para correspondência. e-mail: re_conbr@yahoo.com.br

\begin{abstract}
RESUMO. O ensaio in vitro objetivou avaliar o efeito do álcool PA e de diferentes concentrações $(5 \%, 10 \%$ e $15 \%)$ no Agar, do Extrato Alcoólico de Própolis (EAP), de três regiões do Estado de São Paulo, sobre a Pasteurella multocida, obtida a partir de swab nasal de coelhos. Por meio de outro ensaio, analisou-se o comportamento dessas bactérias em lavado tráqueo-brônquico de coelhos, alimentados com rações contendo álcool PA e diferentes concentrações de $\operatorname{EAP}(0,1 \% ; 0,2 \%$ e $0,3 \%)$. O álcool só foi efetivo na inibição do desenvolvimento bacteriano in vitro na concentração mais elevada, enquanto o EAP demonstrou efetividade em todas as concentrações. As amostras de própolis das três regiões não diferiram entre si. No lavado tráqueo-brônquico, o número de Unidades Formadoras de Colônias por mililitro não diferiu entre os tratamentos, porém houve uma tendência de maior efetividade nos tratamentos com EAP em relação ao álcool, acompanhando a ação in vitro.
\end{abstract}

Palavras-chave: própolis; Pasteurella multocida; coelhos.

ABSTRACT. Efiect of alcohol extract of propolis on the Pasteurellat multocida in vitro and in the rabbits. The essay in vitro aimed to evaluate the effect of alcohol and different concentrations (5, 10 and 15\%) in the agar, of Alcoholic Extract of Propolis (AEP), from three regions of São Paulo State, Brazil, on Pasteurella multocida, obtained from rabbits' nasal swabs. In other essay the reaction of this bacteria was observed. In tracheal regions of rabbits, fed on diets with alcohol and AEP in different concentrations $(0.1 ; 0.2$ and $0.3 \%)$. The alcohol was only effective on the inhibition of the bacteria in vitro on highest concentration, while the AEP was effective in all concentrations. The propolis samples from three regions did not differ. In the other assay, there wasn't any difference between treatments, but the AEP showed to be more active than alcohol against Pasteurella multocida, in the tracheal region of the rabbits, as to the action in vitro.

Key words: propolis; Pasteurella multocida; rabbits.

\section{Introdução}

De acordo com Cueto (1989), as plantas possuem um eficiente poder protetor, sintetizando produtos de elevadas qualidades antimicrobianas e imunológicas. As abelhas, com incrível capacidade biosseletora, coletam as resinas de que necessitam $\mathrm{e}$ as transformam com uma enzima produzida por suas glândulas salivares, fornecendo-lhes ácidos graxos insaturados que potencializam as propriedades terapêuticas das resinas vegetais. Como exemplo, a molécula de pinocembrina, flavonóide presente na resina de algumas árvores que, ao ser processada pelas abelhas, adquire um íon que lhe faculta propriedades fotoinibidoras. Ainda segundo esse autor, a defesa antimicrobiana das plantas é o princípio geral que explica a natureza antimicrobiana da própolis. De acordo com Rojas (1989), o poder germicida da própolis é tão marcante que, se algum animal penetra na colméia, as abelhas, após matá-lo, recobrem-no com própolis, mumificando-o. Embora seja utilizada desde a antiguidade como antibiótico natural, de acordo com Grange e Davey (1990), a natureza dos componentes antimicrobianos da própolis ainda não foi elucidada, embora existam evidências que apontem os flavonóides e vários ésteres do ácido caféico (ácido fenólico), como responsáveis por esse efeito.

A composição química da própolis varia de acordo com a origem botânica dos exsudatos coletados pelas abelhas, como tem sido demonstrado por vários autores, estudando própolis de diferentes origens geográficas. Ghisalberti et al. (1977), analisando a composição bioquímica da própolis do Oeste da Austrália, isolaram 4 flavononas nunca isoladas e as associaram àquelas encontradas em algumas plantas comuns da região, bem como GarciaVigueira et al. (1993), que, estudando a composição química da própolis do Canadá, relacionaram a pinocembrina (flavonona), a crisina e a galangina (flavonas) ao Populus americano, enquanto a própolis 
originária do Populus europeu (Populus nigro) caracterizou-se pela presença de altos níveis de ácidos caféico e isoferúlico e seus ésteres.

Segundo Marcucci (1995), em análises de amostras de própolis de diferentes partes do mundo, foi observado que a composição química daquelas amostras procedentes da Europa, Ásia e América do Norte não foi muito variável, pois as fontes florais principais são algumas espécies de choupo, principalmente o preto (Populus nigro). Os mais importantes componentes dessas amostras de própolis foram os fenólicos: flavonóides, ácidos aromáticos e seus ésteres (cerca de $50 \%$ do peso da própolis). Entretanto, a composição química e a origem das resinas da América do Sul são de especial interesse pela riqueza da flora, sendo que amostras da própolis oriundas do Brasil e da Venezuela confirmaram a presença de compostos incomuns e os flavonóides, por exemplo, foram muito pouco observados, sendo mais comuns os ácidos fenólicos.

Nieva Moreno et al. (1999) compararam amostras de própolis de quatro localidades de Almaicha del Valle (província de Tucumán) e de Cerrillo (província de Santiago de Estero), uma outra região fitogeográfica da Argentina. A análise cromatográfica das amostras das regiões de Almaicha del Valle foram semelhantes entre si, mas diferiram da amostra de Cerrillo, indicando diferenças quanto às composições das mesmas.

Investigando a composição química da própolis brasileira de regiões diferentes, Marcucci (1999) encontrou vários compostos novos, alguns de interesse particular, especialmente um derivado do ácido cumárico, pois apresentou atividade antibacteriana e antitumoral significativas. Estes compostos estão presentes em muitas amostras de regiões diferentes no Brasil, e sua fonte é o exsudato das folhas de algumas espécies de Baccharis spp. (vassourinha ou alecrim-do-campo). De acordo com o autor, isso demonstra a importância dos ácidos fenólicos para a padronização e controle de qualidade da própolis.

Em relação às propriedades biológicas, sua atividade antibacteriana tem sido a mais estudada, sendo consenso entre os autores que a própolis é ativa principalmente contra bactérias Gram positivas, havendo, entretanto, atividade limitada contra bactérias Gram negativas. Fernandes Jr. et al. (1997) verificaram o efeito bactericida para Staphylococcus aureus entre 6 e 9 horas de exposição à concentração de $2 \%(\mathrm{~V} / \mathrm{V})$ de EAP, e efeito bacteriostático com concentrações $0,5 \%$ e $1,5 \%$. Porém, para Escherichia coli, embora o efeito bactericida também fosse observado entre 6 e 9 horas de exposição, foram necessárias concentrações significativamente maiores (10\% e $11 \%)$. Sforcin (1996), testando a atividade antimicrobiana in vitro da própolis sobre linhagens bacterianas isoladas de processos infecciosos humanos, também constatou a inibição do crescimento de bactérias Gram positivas em baixas concentrações $(0,4 \%)$, enquanto as Gram negativas foram menos susceptíveis a este apiterápico, sendo a concentração mínima inibitória de 4,5\% a 8\%.

Entre as bactérias testadas, estão algumas espécies dos gêneros: Staphylococcus, Enteroccocus, Streptococcus, Corynebacterium, Bacillus, Salmonella, Shiguella, Enteroabcter, além de Branhamella catarrhalis, Sarratia marcencens, Escherichia coli, Pseudomonas aeruginosa, Proteus mirabilis, Prototheca zopfii, Rhodococcus equi, Geothrichum candidum, Klebsiella pneumoniae, entre outras (Rojas, 1989; Grange e Davey, 1990; Langoni et al., 1994; Fernandes Jr. et al., 1995, 1997; Tosi et al., 1996; Nieva e Moreno et al., 1999; Kujumgiev et al., 1999, entre outros). Grande parte dessas bactérias demonstrou resistência à maioria dos antibióticos tradicionais.

Takaisi-Kikuni e Schilcher (1994), por meio de micro-calorimetria e de microscopia eletrônica, utilizando Streptococcus agalactiae, demonstraram que a própolis inibiu o crescimento bacteriano por impedir a divisão celular, desorganizando o citoplasma, a membrana citoplasmática e a parede celular, causando uma lise bacteriana parcial e inibindo a síntese protéica. De acordo com os autores, ficou evidente que o mecanismo de ação da própolis sobre células bacterianas é complexo e que não pode ser feita uma simples analogia ao modo de ação de alguns antibióticos clássicos.

A Pasteurella multocida é a bactéria mais comum nos coelhos de laboratório, mas, em situações de estresse dos animais, por temperatura, umidade e pelo próprio manejo, pode causar problemas de ordem respiratória, reprodutiva e neurológica, diminuindo o desempenho produtivo e reprodutivo dos mesmos (De Long e Manning, 1994). Segundo os autores, muitas dessas manifestações clínicas são refratárias a antibióticoterapia e não há relatos de estratégia de vacinação que possa prevenir todas as manifestações da doença.

O objetivo do presente estudo foi verificar a atividade in vitro da própolis sobre a Pasteurella multocida, bactéria Gram negativa, bem como observar o efeito do extrato alcoólico de própolis adicionado à ração, sobre bactérias do mesmo gênero e espécie, em coelhos adultos.

\section{Material e métodos}

\section{Coleta de própolis}

Foram coletadas amostras de própolis de apiários nos municípios de Luiz Antonio, de Marília (Universidade de Marília - Unimar) e de Botucatu (Faculdade de Medicina Veterinária e Zootecnia Unesp, localizado na Fazenda Experimental Lageado), todos no Estado de São Paulo. 
A própolis foi coletada de colônias de abelhas africanizadas Apis mellifera L., alojadas em colméias de madeira, modelo Langstroth.

A coleta foi realizada mediante a colocação de quadros extratores de própolis entre o ninho e a tampa das colméias, no período de agosto a dezembro de 1999. Assim que os espaços dos extratores foram preenchidos com própolis pelas abelhas, essa foi raspada, colocada em sacos plásticos e armazenada ao abrigo da luz.

\section{Preparo dos Extratos Alcoólicos de Própolis (EAP)}

Foram preparadas tinturas de própolis da seguinte forma: a própolis foi pesada, triturada, colocada em uma vasilha de vidro e coberta com álcool etílico PA $\left(90^{\circ} \mathrm{GL}\right)$, a $30 \%$ (peso/ peso). Essa vasilha foi tampada hermeticamente e mantida por 10 dias à temperatura ambiente, protegida da luz, sob agitação freqüente (Sforcin, 1996). Decorrido esse período, as soluções foram filtradas e armazenadas protegidas da luz.

Para o ensaio da susceptibilidade bacteriana in vitro, foram preparados extratos com as amostras de própolis de cada região a ser testada. O EAP, adicionado às rações para o teste in vivo, foi preparado a partir da mistura de amostras de própolis dos apiários de Marília e de Botucatu, citados acima.

\section{Susceptibilidade de Pasteurella multocida frente ao extrato alcoólico de própolis}

Os testes para determinar a sensibilidade da Pasteurella multocida ao EAP foram realizados no laboratório de Zoonoses Bacterianas e Fúngicas do Departamento de Higiene Veterinária e Saúde Pública da FMVZ - Unesp - Campus de Botucatu, Estado de São Paulo.

Foram utilizadas amostras de Pasteurella multocida isoladas em meio de ágar sangue bovino a $10 \%$, incubadas a $37^{\circ} \mathrm{C}$, por até 96 horas. As amostras foram obtidas a partir de swabs nasais, de coelhos do Setor de Cunicultura da FMVZ. A identificação do referido agente foi realizada de acordo com Qüinn et al. (1994), verificando-se a produção de hemólise, crescimento em Agar MacConkey, produção de indol, de urease, ornitina descarboxilase e acidificação de glicose, lactose, sacarose, maltose e manitol, além das características morfológicas e tintoriais, de acordo com a técnica de Gram. O inóculo de Pasteurella multocida a ser utilizado foi padronizado na concentração de $5 \times 10^{5}$ unidades formadoras de colônias por mililitro (UFC/mL).

Foram testadas 3 diluições do EAP (V/V): 5\%, $10 \%$ e $15 \%$, para cada uma das soluções obtidas nas três regiões, e o grupo controle com $5 \%, 10 \%$ e $15 \%$ de álcool etílico PA, com 3 repetições por tratamento, em meio de Agar cérebro-coração. $\mathrm{O}$ extrato ou o álcool, nas diferentes concentrações, foi adicionado ao meio de cultura ainda líquido à temperatura de $45^{\circ} \mathrm{C}$, homogeneizando-se cuidadosamente sob movimentos rotatórios, distribuindo-se em placas de Petri, em volume de $20 \mathrm{~mL}$. Após controle de esterilidade até 24 horas a $37^{\circ} \mathrm{C}$, foram adicionados $0,1 \mathrm{~mL}$ do inóculo às placas, espalhando-o sobre as mesmas, com o auxílio de bastão de vidro estéril, incubando-se a $37^{\circ} \mathrm{C}$, por até 72 horas, com observação do desenvolvimento microbiano a cada 24 horas.

\section{Recuperação de Pasteurella multocida após a utilização de rações contendo extrato alcoólico de própolis}

Segundo De Long e Manning (1994), a infecção por essa bactéria geralmente inicia-se na cavidade nasal, quando o animal é portador, então se propaga para outras partes do sistema respiratório por extensão direta, ou para outras partes do corpo via sangüínea. Tendo-se em vista essas observações, optou-se por fazer uma amostragem da secreção traqueal dos animais, que oferece dados mais confiáveis relacionados à contaminação dos mesmos por Pasteurella multocida, obtendo-se essa a partir de lavado tráqueo-brônquico.

Este ensaio foi realizado no Setor de Cunicultura da FMVZ-Unesp-Botucatu, utilizando-se 40 fêmeas jovens, da raça Norfolk 2000, linhagem Botucatu, com idade média de $97 \pm 4,18$ dias e peso médio de 3273,5 \pm $293,03 \mathrm{~kg}$, no início do experimento. Essas foram submetidas à traqueotomia para obtenção do lavado traqueal, no Setor de Cunicultura. Os animais receberam como medicação pré-anestésica a Acepromazina a $0,2 \mathrm{mg} / \mathrm{kg}$ de peso vivo, via intramuscular, e Diazepan, a $10 \mathrm{mg} / \mathrm{kg}$ de peso vivo, associado ao cloridrato de Ketamina, a $4 \mathrm{mg} / \mathrm{kg}$ de peso vivo, via intravenosa. Em seguida, realizou-se a traqueotomia e o lavado traqueal foi obtido injetando-se $3 \mathrm{~mL}$ de solução salina estéril a $0,9 \%(\mathrm{NaCl})$, por animal, via transtraqueal, utilizando-se seringa descartável de igual volume e agulha 30x7, procurando-se recuperar pelo menos $1 \mathrm{~mL}$ do inóculo.

As amostras foram transportadas ao Laboratório em isopor com gelo, e submetidas às diluições de $10^{-1}$ e $10^{-2}$, sendo que $0,1 \mathrm{~mL}$ de cada diluição foi semeado em placas contendo Agar sangue bovino (10\%) e Agar Mac Conkey. As placas foram incubadas a $37^{\circ} \mathrm{C}$ e foram realizadas leituras após 24,48 e 72 horas, a fim de serem observados o desenvolvimento e a contagem das unidades formadoras de colônias (UFC/mL).

Os animais foram devolvidos sedados às respectivas gaiolas e, em média 2 horas após a intervenção, estavam ativos, alimentando-se e bebendo água.

Foram realizadas 2 coletas de lavado traqueal por animal, nos dias 1 de fevereiro e 9 de março de 2000, ou seja, antes e após o fornecimento das rações tratadas, respectivamente. 


\section{Fornecimento de rações tratadas}

O álcool e o Extrato Alcoólico de Própolis (EAP), nas diferentes concentrações descritas abaixo, foram incorporados às rações no misturador de Premix, antes da peletização das mesmas. Uma amostra do EAP foi enviada ao laboratório de Bromatologia da FMVZ para análise.

As rações foram preparadas e peletizadas na fábrica de rações da FMVZ, e sua composição pode ser observada na Tabela 1.

Tabela 1. Composição percentual e química ${ }^{1}$ da ração de coelhos utilizada (categoria de reprodutores)

\begin{tabular}{lc}
\hline Ingredientes & Porcentagem \\
\hline Milho moído & 30,00 \\
Farelo de Soja & 33,02 \\
Farelo de Trígo & 1,55 \\
Feno de Brachiaria decumbens & 27,53 \\
Óleo de soja & 2,99 \\
Sal & 0,89 \\
Calcário & 0,59 \\
Fosfato bicálcico & 2,73 \\
Mistura mineral e vitamínica & 0,70 \\
\hline Total & 100,00 \\
\hline Energia Digestível (Kcal/kg) & 2750 \\
Proteína Bruta (\%) & 18,84 \\
Fibra em Detergente Neutro (\%) & 27,22 \\
Fibra em Detergente Ácido (\%) & 15,84 \\
Ca (\%) & 1,10 \\
P (\%) & 0,80 \\
Metionina + Cistina & 0,60 \\
\hline 'Composição química estimada com base nos valores tabelados dos alimentos (Valadares \\
Filho, 2000); ${ }^{2}$ Composição do Premix Suprevit*: ácido fólico - $100 \mathrm{mg}$; antioxidante - \\
40mg; cobre - 2400mg; coccidiostático - 6,6g; colina - 25g; ferro - 16.000mg; iodo - \\
200mg; manganês - 12.000mg; niacina - 6.000mg; selênio - 40mg; vitamina A - 1.400.000 \\
UI; vitamina B1 - 500mg; vitamina B12 - 2.500mg; vitamina B2 - 1.000mg; vitamina B6 - \\
400mg; vitamina D3 - 250.000 UI; vitamina E - 7.000mg; vitamina K3 - 400mg; zinco - \\
10.000mg; pantotenato de cálcio - 2.000mg; veículo q.s.p. 1.000g.
\end{tabular}

As rações experimentais foram fornecidas a partir de 04/02/2000. O período de 4 dias, até 08/02/2000, foi considerado de adaptação, não se considerando os dados de consumo nas análises estatísticas.

Os animais, após a obtenção do lavado traqueal, foram distribuídos casualmente (8 repetições) em 5 tratamentos, de acordo com o tipo de ração:

- Tratamento 1: grupo controle: ração pura;

- Tratamento 2: álcool PA - 25,86mL/kg de ração;

- Tratamento 3: 8,62mL de Extrato Alcoólico de Própolis (EAP)/ kg de ração - 1000 ppm ou $0,1 \%$ de Extrato Seco de Própolis (ESP);

- Tratamento 4: 17,24mL de EAP/ kg de ração 2000 ppm ou $0,2 \%$ de ESP;

- Tratamento 5: 25,86mL de EAP/ $\mathrm{kg}$ de ração 3000 ppm ou $0,3 \%$ de ESP.

O Extrato Alcoólico de Própolis foi preparado como descrito acima, porém a própolis bruta foi uma mistura daquelas obtidas nas regiões de Botucatu e de Marília. Quando o extrato estava pronto, foram tomadas 10 amostras de $10 \mathrm{~mL}$ e colocadas em Beckers na estufa a $65^{\circ} \mathrm{C}$ por 72 horas e depois a $105^{\circ} \mathrm{C}$, até que seus pesos secos se estabilizassem (aproximadamente 5 dias). A média das 10 amostras foi de $116 \mathrm{mg}$ de extrato seco por mililitro de Extrato
Alcoólico. Os cálculos das quantidades de Extrato Alcoólico nos diferentes tratamentos foram feitos com base no peso do extrato seco. Sempre que for citado um tratamento com determinada proporção de Extrato Alcoólico de Própolis $(0,1 \% ; 0,2 \%$ ou $0,3 \%)$, subentende-se que essas proporções são referentes ao peso de extrato seco de própolis por quantidade de ração (peso/ peso).

As rações tratadas foram fornecidas do dia $1^{\circ}$ de fevereiro ao dia 8 de março de 2000, totalizando 37 dias. Foram fornecidos $250 \mathrm{~g}$ de ração por animal por dia, completando-se as sobras e, semanalmente, calculando-se o consumo pela diferença entre o fornecido e as sobras.

\section{Análises estatísticas}

Os dados referentes ao teste de susceptibilidade in vitro de Pasteurella multocida às diferentes concentrações de própolis de diferentes regiões foram comparados estatisticamente pelo Teste do Quiquadrado.

Os dados referentes ao número de unidades formadoras de colônias de Pasteurella multocida por mililitro de lavado tráqueo-brônquico dos coelhos foram transformados, por meio da aplicação do logaritmo de $(x+5)$, visando-se a uma maior homogeneização dos mesmos. Os dados dos tratamentos foram comparados por meio de testes estatísticos não-paramétricos de Kruskal-Wallis e as médias das duas épocas por meio do teste de Wilcoxon, com $5 \%$ de probabilidade.

$\mathrm{O}$ delineamento foi inteiramente casualizado, com 5 tratamentos e 8 repetições por tratamento.

\section{Resultados e discussão}

\section{Susceptibilidade de Pasteurella multocida frente ao extrato alcoólico de própolis}

Os resultados do teste de susceptibilidade de Pasteurella multocida in vitro ao álcool e aos extratos alcoólicos com própolis de três localidades do estado de São Paulo, nas três concentrações estudadas, encontram-se na Tabela 2.

Tabela 2. Pasteurella multocida: estudo da susceptibilidade in vitro, frente ao álcool e ao extrato alcoólico de própolis, de três regiões do estado de São Paulo, em três diferentes concentrações $(5 \%, 10 \%$ e $15 \%-\mathrm{V} / \mathrm{V})$ no meio de cultura (inóculo: $5 \times 10^{5}$ unidades formadoras de colônias)

\begin{tabular}{lccccc}
\hline \multirow{2}{*}{ Tratamentos } & Concentrações & \multicolumn{3}{c}{ Tempo de leitura } & Resultado \\
\cline { 2 - 5 } & $(\%)$ & 24 horas & 48 horas & 72 horas & Final \\
\hline Álcool & 5 & 0 & 0 & 0 & 0 \\
& 10 & 0 & 0 & 0 & 0 \\
Própolis de & 15 & + & + & + & + \\
Botucatu & 5 & + & ++ & ++ & ++ \\
& 10 & ++ & ++ & ++ & ++ \\
Própolis de & 15 & ++ & ++ & ++ & ++ \\
Marília & 5 & ++ & ++ & ++ & ++ \\
& 10 & ++ & ++ & ++ & ++ \\
Própolis de & 15 & ++ & ++ & ++ & ++ \\
& 5 & ++ & ++ & ++ & ++
\end{tabular}


\begin{tabular}{llllll} 
Luiz Antonio & 10 & ++ & ++ & ++ & ++ \\
& 15 & ++ & ++ & ++ & ++ \\
\hline
\end{tabular} Obs: Os graus de inibição estão simbolizados por: $\mathbf{0}$ - sem inibição (incontáveis UFC); + inibição parcial ( $256 \mathrm{UFC} / \mathrm{mL})$; ++ - inibição total (sem crescimento de colônias).

Pela tabela pode-se observar que as duas concentrações mais baixas de álcool no meio Agar $(5 \%$ e $10 \%)$ não inibiram o desenvolvimento bacteriano e a concentração mais elevada (15\%) inibiu apenas parcialmente, enquanto os extratos alcoólicos, independentemente da concentração no meio $(5 \%, 10 \%$ ou $15 \%)$, inibiram completamente o crescimento bacteriano.

Estes dados foram comparados estatisticamente pelo Teste do Qui-quadrado, visto que, para a maioria dos tratamentos, não houve desenvolvimento de colônias e, quando houve, o número de colônias formadas foi extremamente elevado e estas foram confluentes, impossibilitando sua contagem. O teste indicou diferença significativa $\left(\chi_{c}^{2}=6,0\right)$, ao nível de $5 \%$ de significância, entre os graus de inibição de desenvolvimento de colônias de bactérias nos meios com álcool e aqueles com extrato alcoólico de própolis, nas três concentrações testadas.

Esses resultados estão de acordo com aqueles observados por Sforcin (1996), que verificou que o álcool etílico PA apresentou ação inibitória sobre o crescimento bacteriano apenas na concentração de $15 \%$, valor muito acima do obtido com EAP, sendo de $8 \%$ a Concentração Inibitória Mínima (CIM) mais elevada, observada para Escherichia coli e Salmonella typhimurium. Concluiu que a atividade antibacteriana verificada no ensaio foi devida exclusivamente aos componentes da própolis. Nieva Moreno et al. (1999) também não observaram efeito antibacteriano do etanol $(80 \%)$, tanto pela técnica da difusão em discos de papel, como pela análise de bioautografia de contato, enquanto para os extratos etanólicos de própolis o aumento da inibição foi proporcional ao aumento das concentrações do extrato.

Quanto ao efeito do extrato alcoólico de própolis sobre a Pasteurella multocida, Sforcin (1996) também observou inibição do crescimento de bactérias Gram negativas frente a esse extrato, embora em concentrações mais elevadas do que as necessárias para inibir as bactérias Gram positivas. Enquanto a CIM do extrato alcoólico de própolis para Staphylococcus aureus foi de $0,40 \%$, para Pseudomonas aeruginosa, essa concentração foi em torno de $5,70 \%$ e, tanto Escherichia coli quanto Salmonella typhymurium, demonstraram-se mais resistentes, com CIM de $8 \%$. Nesse experimento, o EAP à concentração de $5 \%$ inibiu o desenvolvimento de colônias de $P$. multocida.

Os extratos preparados com própolis dos três diferentes municípios do estado de São Paulo não apresentaram diferenças entre si, com relação à inibição do crescimento de Pasteurella multocida.
Alguns autores têm estudado a correlação entre a atividade biológica da própolis e suas diferentes composições, de acordo com suas regiões de origem. Boudorova-Krasteva et al. (1997) avaliaram a própolis extraída na Área de Produção de Apicultura da Faculdade de Medicina Veterinária e Zootecnia de Botucatu, local onde foi realizado o presente estudo, e isolaram 6 compostos individuais, sendo que 3 deles têm sido encontrados por outros autores em diferentes espécies de Baccharis (gênero muito difundido na América do Sul) e, de acordo com Marcucci (1999), estão presentes em muitas amostras de própolis do Brasil. Parte da própolis utilizada neste experimento, da região de Botucatu, provavelmente tenha composição química semelhante a esta discutida pelos autores acima, já que Sforcin (1996), utilizando própolis desse mesmo local, obtidas em 4 diferentes épocas do ano, não observou diferenças significativas entre elas, quanto à ação biológica, e que a flora local não sofreu severas alterações nos últimos anos.

Essa semelhança de ação antimicrobiana entre própolis de diferentes municípios da região Sudeste está de acordo, de certa forma, com uma tendência observada por alguns autores, como Moura et al. (1999), que não observaram grande variação no perfil cromatográfico de amostras de própolis da região Sudeste do Brasil, e também verificaram que todas as amostras inibiram mais o crescimento de Staphylococcus aureus do que de Streptococcus mutans. Kujumgiev et al. (1999) avaliaram a atividade anti-bacteriana de extrato alcoólico e óleos voláteis de própolis de diferentes regiões geográficas: Bulgária, Albânia, Mongólia, duas localidades do Egito, quatro localidades do Brasil (Rio Claro e Limeira - SP, Prudentópolis - PR e Pacajus - CE), duas localidades das Ilhas Canárias, além de duas amostras brasileiras coletadas por abelhas sem ferrão (gênero Meliponas). Embora uma amostra de extrato alcoólico e de óleo volátil de própolis das Ilhas Canárias e de uma das amostras coletadas por Meliponas no Brasil tenham mostrado atividade antibacteriana ligeiramente maior, concluíram que, de maneira geral, a atividade antibacteriana foi semelhante, independentemente de suas diferentes composições bioquímicas, atribuindo as propriedades anti-bacterianas da própolis não a uma ou outra substância isolada, mas às diferentes combinações delas, presentes nas diferentes amostras.

Alencar et al. (1999), considerando outra região geográfica brasileira que apresenta grande diversidade de vegetação, analisaram a composição química e a atividade biológica de própolis de diferentes cidades da região Nordeste do Brasil, e verificaram que suas composições variaram de acordo com o tipo de vegetação local, e também que as amostras de própolis da mata atlântica mostraram maior atividade antimicrobiana frente a Staphylococcus aureus e Streptococcus mutans, 
sendo, entretanto, superadas, em termos de ação antioxidante, pelas própolis originárias da caatinga baiana. Comparando diferentes regiões brasileiras, Koo et al. (1999) verificaram que os perfis cromatográficos das amostras da região Sudeste foram nitidamente diferentes daqueles das amostras da região Sul, e a atividade antibacteriana do extrato etanólico do Rio Grande do Sul foi de 4 a 8 vezes mais potente que a de Minas Gerais.

\section{Recuperação de Pasteurella multocida após a utilização de ração contendo extrato alcoólico de própolis}

Uma amostra do Extrato Alcoólico incorporado à ração foi enviada ao laboratório de Bromatologia da FMVZ para análise. A composição bromatológica (em 100\% de matéria seca) foi a seguinte: $17,84 \%$ de matéria seca; $1 \%$ de proteína bruta; $96,06 \%$ de extrato etéreo e $0,42 \%$ de minerais.

Considerando-se o desenvolvimento de colônias de Pasteurella multocida na região tráqueo-brônquica dos coelhos testados, os dados referentes ao número de Unidades Formadoras de Colônias (UFC)/mL de inóculo obtido desta região (duas diluições), antes e após o fornecimento das rações contendo três níveis de Extrato Alcoólico de Própolis (EAP) e álcool, estão resumidos na Tabela 3. Os dados referem-se ao número de $\mathrm{UFC} / \mathrm{mL}$ nas placas, com diluição do inóculo a $10^{-2}$, uma vez que em $10^{-1}$ as colônias foram incontáveis. Os resultados dos testes nãoparamétricos de Kruskal-Wallis e de Wilcoxon também são apresentados na mesma tabela. A análise não-paramétrica foi realizada em função dos dados não se ajustarem aos critérios exigidos para a análise de variância.

Tabela 3. Pasteurella multocida: médias e desvios-padrão dos números de unidades formadoras de colônias por mililitro de lavado traqueal de coelhos ( 8 por tratamento), alimentados com rações com diferentes quantidades de Extrato Alcoólico de Própolis - EAP (cálculo sobre o extrato seco - peso /peso), ou com álcool, antes e após o fornecimento das mesmas. Os números entre parênteses referem-se aos dados transformados por $\log (\mathrm{x}+5)$, para efeito de análise estatística

\begin{tabular}{lcc}
\hline Tratamentos & $\begin{array}{c}\text { Antes do fornecimento das rações } \\
\text { Unidades formadoras } \\
\text { de colônias/mL }\end{array}$ & $\begin{array}{c}\text { Após o fornecimento das rações } \\
\text { Unidades formadoras } \\
\text { de colônias } / \mathrm{mL}\end{array}$ \\
\hline Controle & $118,50 \pm 250,08$ & $150,25 \pm 401,62$ \\
& $(1,3629 \pm 0,8362)$ & $(1,2792 \pm 0,7799)$ \\
Álcool & $306,12 \pm 749,61$ & $313,87 \pm 484,94$ \\
& $(1,5125 \pm 0,9319)$ & $(1,6020 \pm 1,0780)$ \\
$0,1 \%$ EAP & $275,12 \pm 624,36$ & $(0,8852 \pm 0,11$ \\
& $(1,6037 \pm 0,9093) \mathrm{a}$ & $186,12 \pm 526,04) \mathrm{b}$ \\
$0,2 \%$ EAP & $184,12 \pm 513,94$ & $(1,0182 \pm 0,8715) \mathrm{b}$ \\
& $(1,1078 \pm 0,8541) \mathrm{a}$ & $4,63 \pm 9,21$ \\
$0,3 \%$ EAP & $120,63 \pm 326,41$ & $(0,8827 \pm 0,2738)$ \\
& $(1,1291 \pm 0,8038)$ & $131,67 \pm 367,44$ \\
Geral & $200,90 \pm 504,74$ & $(1,1334 \pm 0,7436)$ \\
& $(1,3432 \pm 0,8469)$ & .
\end{tabular}

Pode-se observar a grande variabilidade dos dados pelos altos valores de desvios-padrão estimados, tanto quando são considerados todos os dados, como quando se consideram os valores observados dentro de cada tratamento. Pelo teste de Kruskal-Wallis, não foram encontradas diferenças significativas entre as médias dos tratamentos após o fornecimento de rações tratadas, porém, quando foram comparados os tratamentos controle e $0,2 \%$ de EAP, bem como este com o álcool, as diferenças observadas $(12,13 \mathrm{e}$ 12,50 , respectivamente) aproximaram-se bastante da diferença mínima significativa $(15,94)$, ao nível de $5 \%$.

Os testes de Wilcoxon, comparando as médias entre épocas, em cada tratamento, indicaram que houve uma redução significativa no número de UFC $/ \mathrm{mL}$ de Pasteurella multocida no lavado tráqueobrônquico dos animais que receberam rações com $0,1 \%$ de EAP (significância de 4,22\%) e $0,2 \%$ de EAP $(2,8 \%)$, não diferindo para os outros tratamentos, embora os que receberam tratamento com $0,3 \%$ também tenham apresentado uma tendência de redução.

Estes resultados, até certo ponto, confirmam os obtidos para a análise do efeito do EAP sobre a Pasteurella multocida in vitro, discutidos no item anterior, os quais demonstraram que esse extrato, nas concentrações testadas, foi efetivo na inibição do crescimento bacteriano, enquanto o álcool PA, utilizado como solvente, só demonstrou atividade parcial na concentração mais elevada. Assim, tanto in vitro quanto in vivo, o extrato alcoólico de própolis foi mais efetivo que o solvente utilizado (álcool) contra o desenvolvimento dessa bactéria Gram negativa, demonstrando o efeito antimicrobiano da própolis.

Outro ponto importante a ser considerado nesta análise é que, durante o período experimental, os animais foram submetidos ao estresse, já que foram realizados dois lavados tráqueo-brônquicos e três coletas de sangue (discutidas em outro trabalho), além da mudança alimentar. $\mathrm{O}$ estresse dos animais, de acordo com De Long e Manning (1994), pode desencadear problemas de ordem respiratória, reprodutiva e neurológica, provocados pela Pasteurella multocida, embora esta seja uma bactéria comum nos coelhos, pertencente a microbiota do aparelho respiratório superior. Nesse aspecto, o fornecimento de extrato alcoólico de própolis pode ter atuado na prevenção desses quadros, uma vez que, mesmo sob situações que causam estresse, os animais que receberam os extratos, nas concentrações $0,1 \%$ e $0,2 \%$, apresentaram redução na carga bacteriana tráqueo-brônquica.

Os resultados obtidos nesse estudo estão de acordo com dados da literatura referentes à análise in vitro, já citados acima, embora a maioria dos autores tenha demonstrado a efetividade da própolis contra 
bactérias Gram positivas. Poucos trabalhos, porém, têm discutido o efeito da própolis sobre bactérias em animais, especialmente quando se trata de bactérias Gram negativas.

Considerando-se algumas doenças fatoriais dos animais, que podem ser desencadeadas por estresse, Rodriguez et al. (1989) observaram o efeito clínico do produto NB-2, preparado a partir da própolis, sobre a pneumonia de bezerros, geralmente provocada por microrganismos como Klebsiella sp., Escherichia coli, Salmonella sp., Pasteurella mutocida, Arcanobacterium pyogenes, IBR, PI3 e leveduras. Tanto com administração subcutânea, quanto por via intramuscular, em casos agudos e crônicos, concluíram que o produto apresentou eficácia terapêutica e efeito antibiótico. Fumero et al. (1989) compararam os tratamentos com NB1, outro produto comercial à base de própolis, com a oximicina, sobre a síndrome diarréica em bezerros, em um local com foco ativo de salmonelose e colibacilose. Os resultados indicaram uma recuperação de $100 \%$ dos animais tratados com NB, às 72 horas, e para a oximicina, efeitos mais retardados e maior número de tratamentos.

Em relação a protozoários, Hollands et al. (1984, 1988 e 1989) testaram a atividade da própolis sobre coccidiose em coelhos, provocada por protozoários do gênero Eimeria, administrando extrato alcoólico de própolis a $2 \%$ ou $3 \%$, via oral, na água. No primeiro trabalho, testaram em 18 coelhos, por 15 dias e observaram uma redução significativa da intensidade da doença, medida pela presença de oocistos nas fezes nos animais tratados, sendo que o extrato a $3 \%$ foi mais efetivo nessa redução em relação àquela observada nos animais do grupo controle (álcool a $95^{\circ}$ ). No segundo experimento, os autores compararam a própolis e sulfonamidas (sulfametazina e sulfaquinoxalina), habitualmente utilizadas como coccidiostáticos em coelhos, utilizando 12 animais, e verificaram reduções significativas na intensidade da coccidiose, nos 2 grupos tratados com as sulfonamidas $(0,1 \%$ e $0,2 \%) \mathrm{e}$ com própolis $(3 \%)$, após o tratamento, não havendo redução no grupo controle (álcool a $95^{\circ}$ ). No terceiro trabalho, os autores acompanharam a mortalidade e a incidência de diarréia em 80 coelhos, 40 tratados com propolina e 40 no grupo controle (álcool a 95\%), observando um período de recuperação duas vezes maior dos animais do grupo controle em relação aos animais tratados, sendo as mortalidades de $10 \%$ e $30 \%$, respectivamente, nos animais dos grupos citados. Concluíram que a propolina pode ser utilizada para combater a coccidiose, sendo um tratamento mais econômico, aumentando a produtividade pela redução na mortalidade. Moura et al. (1998) também testaram o efeito do fornecimento de própolis $(0 \mathrm{~mL}, 4 \mathrm{~mL}, 8 \mathrm{~mL}, 12 \mathrm{~mL}$ e $16 \mathrm{~mL}$ de solução hidroalcoólica de própolis/litro de água) como coccidiostático, a coelhos dos 40 dias aos 90 dias de idade, comparando com a robenidina $(0,1 \%$ na ração e água pura) e verificaram que o último tratamento foi mais eficiente como coccidiostático que o primeiro, embora o aumento na concentração da solução hidroalcoólica de própolis, adicionada à água de beber, tenha reduzido linearmente o número de oocitos de Eimeria spp. por grama de fezes.

Mazzuco et al. (1996) testaram a utilização da própolis e do álcool etílico no controle de Salmonella $\mathrm{sp}$, em rações avícolas. A adição da própolis $(2 \%)$ às rações artificialmente contaminadas foi realizada pulverizando-se as soluções sobre as mesmas, já prontas, e realizando-se a homogeneização manual. Foi analisada a presença de bactérias nos cecos, sendo que, segundo os autores, somente a própolis em solução alcoólica apresentou ação sobre a bactéria, enquanto a própolis em pó e em solução aquosa não exerceram efeito sobre a mesma. Os autores atribuíram o efeito bactericida ao álcool da solução.

No experimento da susceptibilidade da Pasteurella multocida frente aos extratos alcoólicos de própolis, in vitro, o efeito da própolis, nas concentrações testadas, contra o desenvolvimento dessas bactérias Gram negativas foi evidente, uma vez que o álcool utilizado como solvente demonstrou uma baixa atividade contra a mesma bactéria. Os resultados obtidos sobre as mesmas bactérias, alojadas na região tráqueo-brônquica dos coelhos, quando estes receberam rações com própolis, também demonstraram sua efetividade. De maneira geral, esses resultados sugerem que a própolis pode ser utilizada para auxiliar no controle dessa bactéria Gram negativa, freqüente nas cuniculturas, a qual pode levar a prejuízos, principalmente em situações de estresse dos animais, como em mudanças bruscas de temperatura e umidade relativa do ar. Como foi discutido por De Long e Manning (1994), não existe vacina que possa prevenir esta doença e a mesma tem demonstrado resistência à antibioticoterapia.

Poderiam ser realizados outros experimentos, simulando-se situações de estresse térmico, por exemplo, e, de preferência, com a inoculação controlada dessa bactéria em diferentes grupos de animais, de forma a se obter maior homogeneidade dentro de cada grupo, para que se pudesse realmente confirmar a efetividade da própolis sobre a pasteurelose em coelhos. Além disso, deve ser feito um levantamento de custos em relação aos quimioterápicos geralmente utilizados, de forma a se recomendar a utilização deste produto natural na cunicultura.

\section{Conclusão}

A própolis demonstrou ação contra a Pasteurella multocida in vitro, e atuou também sobre essa bactéria nos coelhos, quando fornecida incorporada às 
rações, tendendo a reduzir o número de unidades formadoras de colônias dessa bactéria Gram negativa, em nível tráqueo-brônquico dos animais.

Dessa forma, nas condições testadas, a própolis mostrou-se favorável como auxiliar no controle da Pasteurella multocida nos coelhos, uma vez que, principalmente em situações de estresse dos animais, os sintomas respiratórios, reprodutivos e neurológicos provocados por essa doença têm causado prejuízos em algumas cuniculturas.

\section{Referências}

ALENCAR, S. M. et al. Classificação das própolis do Nordeste do Brasil e avaliação de algumas de suas propriedades biológicas. Revista da Universidade de Franca, Franca, v. 7, p. 43, 1999.

BOUDOUROVA-KRASTEVA, V. et al. Phenolics from Brasilian Propolis. Verlag der Zeitschrift für Naturforschung, v. 52, p. 676-679, 1997.

CUETO, D. J. Experiência clínica de los medicamentos elaborados com propoleo. In: ASIS, M., Investigaciones cubanas sobre el propoleo: Memorias del $1^{\circ}$ Simposio sobre los efectos del propoleo en la salud humana y animal, 1988. Varadero. Matanzas: Consejo Científico del Instituto de Medicina Veterinária, Cuba, 1989, p. 259-262.

DE LONG, D.; MANNING, P. J. Bacterial diseases. In: MANNING, P. J. et al. The biology of the laboratory rabbit. 2.ed. New York: Academic Press, 1994, p. 129-148.

FERNANDES JR. A. et al. In vitro activity of propolis against bacterial and yeast pathogens isolated from human infections. J. Venom. Anim. Toxins, Botucatu, v. 1, p. 6369, 1995.

FERNANDES JR. A. et al. Population analysis of susceptibility to propolis in reference strains of Staphylococcus aureus and Escherichia coli. J. Venom. Anim. Toxins, Botucatu, v.3, p. 287-294, 1997.

FUMERO, A. P. et al. Diarreia infecciosa del ternero: Resultados Preliminares de los tratamientos con NB-1 (una modificación de CNB-R5). In: ASIS, M. Investigaciones cubanas sobre el propoleo: Memorias del $1^{\circ}$ Simposio sobre los efectos del propoleo en la salud humana y animal, 1988. Varadero. Matanzas: Consejo Científico del Instituto de Medicina Veterinária, Cuba, 1989, p. 150-151.

GARCIA-VIGUEIRA, C. et al. Study of Canadian Propolis por GC-MS e HPLC. Verlag der Zeitschrift für Naturforschung, v. 48, p. 731-735, 1993.

GHISALBERTI, E. L. et al. Potencial drugs from propolis. In: FRIGERIO, A.; GHISALBERT, E. L Mass spectrometry in drugs metabolism. New York: Plenum Press, 1977, p. 101-120.

GRANGE, J. M.; DAVEY, R. W. Antibacterial properties of propolis (bee glue). J. R. Soc. Med., London, v. 83, p. 159-160, 1990.

HOLLANDS, I. et al. Efficacy of propolis against infection by intestinal Eimeria in rabbits. Rev. Cubana Cienc. Vet., Habana, v. 15, p. 157-163, 1984.

HOLLANDS, I. et al. Comparative analysis of action of propolis, sulphaquinoxalina and sulphamethazina in rabbits whith coccidiosis. Rev. Cubana Cienc. Vet., Habana, v. 19, p. 99-104, 1988.
HOLLANDS, I. et al. El propoleo y sus posibilidades en el tratamiento de la coccidiosis del conejo. In: ASIS, M. Investigaciones cubanas sobre el propoleo: Memorias del $1^{\circ}$ Simposio sobre los efectos del propoleo en la salud humana y animal, 1988. Varadero. Matanzas: Consejo Científico del Instituto de Medicina Veterinária, Cuba, 1989, p. 100-108.

KOO, H. et al. Avaliação do potencial anti-cárie e antiplaca da própolis de Apis mellifera da região Sudeste e Sul do Brasil. II - Efeito in vitro sobre os estreptococos do grupo mutans. Revista da Universidade de Franca, Franca, v.7, p. 47-48, 1999.

KUJUMGIEV, A. et al. Antibacterial, antifungal and antiviral activity of propolis of different geographic origin. J. Ethnopharmacol., Sharmon, v. 64, p. 235-240, 1999.

LANGONI, H. et al. Efeito antimicrobiano in vitro da própolis. In: CONGRESSO IBEROLATINO AMERICANO DE APICULTURA, 4, 1994, Córdoba. Anais... Córdoba, 1994, p.189-192.

MARCUCCI, M. C. Propolis, chemical composition, biological properties and therapeutic activity. Apidologie, Paris, v. 26, p. 83-99, 1995.

MARCUCCI, M. C. Composição química e atividade biológica. Revista da Universidade de Franca, Franca, v.7, p. 17,1999

MAZZUCO, H. et al. Utilização da própolis e álcool etílico no controle de Salmonella em rações avícolas. Scientia Agricola, Jaboticabal, v.53, p. 1-5, 1996.

MOURA, L. P. P. et al. Efeito da solução hidroalcoólica de própolis e robenidina sobre a contagem de oocistos por grama de fezes de Eimeria spp. em coelhos Nova Zelândia Branco. Rev. Bras. Zootec., Viçosa, v. 27, p. 325-330, 1998.

MOURA, F. F. et al. Classificação da própolis da região Sudeste do Brasil. Revista da Universidade de Franca, Franca, v.7, p. 43-44, 1999.

NIEVA MORENO, M. I. et al. Screening of antibacterial activity of Aimacha del Valle (Tucumán, Argentina) propolis. J. Ethnoparmacol., Sharman, v.68, p. 97-102, 1999.

QÜINN, P. J. et al. Clinical Veterinary Microbiology. 2. ed. Spain: Ed. Wolfe, 1994.

RODRIGUEZ, R. et al. Neumonia del ternero: efecto clinico de los antibioticos NB-2, variante del CNB-A17, y la oximicina comercial. ). In: ASIS, M. Investigaciones cubanas sobre el propoleo: Memorias del $1^{\circ}$ Simposio sobre los efectos del propoleo en la salud humana $y$ animal, 1988. Varadero. Matanzas: Consejo Científico del Instituto de Medicina Veterinária, Cuba, 1989, p. 149-150. ROJAS, N. M. Premisas necessarias para la elaboración de medicamentos antimicrobianos a base de propoleo. In: ASIS, M. Investigaciones cubanas sobre el propoleo: Memorias del $1^{\circ}$ Simposio sobre los efectos del propoleo en la salud humana y animal, 1988. Varadero. Matanzas: Consejo Científico del Instituto de Medicina Veterinária, Cuba, 1989, p. 256-259.

SFORCIN, J. M. Efeito da sazonalidade sobre as propriedades imunomoduladora e antibacteriana da própolis e perfil bioquímico dos ratos. 1996. Tese (Doutorado) - Faculdade de Medicina Veterinária e Zootecnia, Universidade Estadual Paulista, Botucatu, 1996. 
TAKAISI-KIKUNI， N. B.; SCHILCHER，H. Electron microscopic and microcalorimetric investigations of the possible mechanism of the antibacterial action of a defined propolis provenance. Planta Medica, Stuttgard, v.60, p. 222-227, 1994
TOSI, B. et al. Antimicrobial activity of some commercial extracts of propolis prepared with different solvents. Phytotherapie Research, v.10, p. 335-336, 1996.

Received on July 03, 2003.

Accepted on January 29, 2004. 